\title{
Spinoza's Political Theory: Naturalism, Determinism and Institutionalism
}

\author{
Jan-Erik Lane \\ Public Policy Institute, Belgrade, Serbia \\ Email: janeriklane34@googlemail.com
}

How to cite this paper: Lane, J.-E. (2017). Spinoza's Political Theory: Naturalism, Determinism and Institutionalism. Open Journal of Philosophy, 7, 105-115.

https://doi.org/10.4236/ojpp.2017.72007

Received: March 25, 2017

Accepted: May 24, 2017

Published: May 27, 2017

Copyright $\odot 2017$ by author and Scientific Research Publishing Inc. This work is licensed under the Creative Commons Attribution International License (CC BY 4.0).

http://creativecommons.org/licenses/by/4.0/

\begin{abstract}
Spinoza has a formidable reputation as an abstract philosopher in the rationalist school of the 17th century. This standard image of him stems from his elegant Ethics, examining men and women with the Euclidean method of axioms, corollaries and implications. He launched a fascinating theory about moral naturalism and ethical determinism, much debated by other great philosophers. However, he also has two political texts, one on religion and another on political regime. They are much more reader friendly and the arguments are simple, following from the foundations in Ethics. At least, Spinoza so believed. This paper presents systematically the political theory in Tractatus Politicus, which has received too little attention.
\end{abstract}

\section{Keywords}

Naturalism, Determinism, Hobbes, Kierkegaard, Monarchy, Aristocracy and Democracy, Institutionalism and Choice

\section{Introduction}

Baruch Spinoza (1632-1677) dealt with general philosophy, the philosophy of religion and political philosophy. This is in no way an extraordinary set of preoccupations. But one may of course point to philosophers who concentrated upon one kind of philosophy to the exclusion of other sorts, like Rousseau, focusing upon political and social philosophy, and e.g. Frege, Austin and Wittgenstein concentrating upon general philosophy, or theoretical philosophy. What is somewhat paradoxical with Spinoza is that his great reputation stems from his Ethics, but his relevance today derives almost exclusive from the two treatises, of which the first on theology is more praised than the second on politics, maybe somewhat undeservedly as I will show.

There are today a few excellent biographies of Spinoza's life and intellectual 
development (Nadler, 1999, 2016; Scruton, 2002; Popkin, 2004), which list his three main works in temporal order:

- Ethics published after his death (Spinoza a);

- Tractatus Theologico-Politicus from 1670 (Spinoza b);

- Tractatus Politicus, published after his death (Spinoza c).

These biographies also look upon the eminence of these three books as descending in the same order. I will try to argue for the originality of Tractatus Politicus.

\section{Naturalism and Determinism}

It is interesting to analyse the argument about politics by Spinoza, because it is based upon his well-known Ethics that has fascinated scholars for its Euclidean form of presentation, aiming at deductive simplicity and logical coherence. Can politics be approached with the two basic ideas of Spinoza, namely naturalism and determinism? Spinoza very much tried, but was he successful, meaning coherent?

It is always stated that Spinoza adheres to rationalism with inspiration from Descartes. Yet, the influence from Hobbes is also obvious. One may ask whether naturalism and determinism could serve as pillars for a remarkable appreciation of the democratic regime, some hundred years before Rousseau.

1) Naturalism

There has been a debate about what Spinoza meant with "nature", especially when he equates the word with "God". Was he an atheist, as the Jewish community accused him, or a pantheist? He states in Ethics:

(Q1) And so by natural right I understand the very laws or rules of nature, in accordance with which everything at place, in other words, the power of nature itself. And so the natural right of universal nature, and consequently of every individual thing, extends as far as its power: and accordingly, whatever any man does after the laws of his nature, he does by the highest natural right, and he has as much right over nature as he has power.

In this key passage, Spinoza reiterates his naturalism from Ethics, meaning that every one does whatever he or she wants. Society is a condition of "natural rights", meaning brutal power or the lack of it-Several commentators have interpreted this naturalism as a form of Stoicism, which is erroneous. Spinoza declines every theory of human rights as natural legal rights (natural law). Spinoza speaks of "natural rights" without any legal connotation, as simply natural capacities or power to safeguard in whatever manner whatever interests a human being may have. We are far from Stoicism and its natural law conception, as a matter of fact much closer to Epicurism of the two great ethical theories during the Ancient period (Long \& Sedley, 1987, 2012).

Spinoza rejects completely Stoicist conceptions of natural sociability, altruism, inalienable human rights, social harmony and the universal soul of all human beings in God. Thus, we read in Ethics:

(Q2) From which it follows that the law and ordinance of nature, under which 
all men are born, and for the most part live, forbids nothing but what no one wishes or is able to do, and is not opposed to strifes, hatred, anger, treachery, or, in general, anything that appetite suggests. For the bounds of nature are not the laws of human reason, which do but pursue the true interest and preservation of mankind, but other infinite laws, which regard the eternal order of universal nature, whereof man is an atom; and according to the necessity of this order only are all individual beings determined in a fixed manner to exist and operate.

This amounts to some version of the message of Epicurus! Society without government is the Hobbesian jungle. Remember that Leviathan was published in 1651, before Tractatus Politicus.

People are bound by nothing in society, as any notion of Stoicist hallmark "Pacts sunt servanda" is foolishness merely:

(Q3) The pledging of faith to any man, where one has but verbally promised to do this or that, which one might rightfully leave undone, or vice versa $\$$, remains so long valid as the will of him that gave his word remains unchanged. For he that has authority to break faith has, in fact, bated nothing of his own right, but only made a present of words. If, then, he, being by natural right judge in his own case, comes to the conclusion, rightly or wrongly (for "to err is human"), that more harm than profit will come of his promise, by the judgement of his own mind he decides that the promise should be broken, and by natural right (Sec. 9) he will break the same.

We could not be further away from the Stoicsts like Grotius, Locke and Kant. This is a 17th century version of Epicurism. He distinguishes between "natural rights" and "legal rights", where the former stands for individual capacity or power and the latter for the ordinances of the commonwealth-positive law (Tuck, 1982). Men and women are guided by emotions and reason in the pursuit of self-preservation-enlightened egoism or rational incentives.

\section{2) Determinism}

Spinoza is perhaps most famous for his determinism that he derives with his Euclidean method-more geometrico. Let us try to pin down this thesis and then inquire into whether it is in agreement with his political arguments, or whether there is a contradiction. His version of determinism reads as follows in a few quotations from Ethics:

(Q4): In nature there is nothing contingent, but all things have been determined from the necessity of the divine nature to exist and produce an effect in a certain way.

(Q5): Things could have been produced by God in no other way, and in no other order than they have been produced.

These propositions have been discussed a lot in the Spinoza literature. They raise questions about free will, indeterminism and voluntarism. Since Spinoza argues that God is part of this determinism, it also leads to a debate about his theology or pantheism.

There are excellent examinations of the theme of determinism-indeterminism, to which I will add nothing here. One may debate whether determinism or inde- 
terminism is warranted from a ontological or epistemological point of view. When determinism appears wrong, then is Spinoza right in claiming a mere ignorance? Is free will incompatible with determinism, and thus a Spinoza illusion?

In Tractatus Politicus, Spinoza sticks to his naturalism and determinism from Ethics, spelling out there implication for politics. There is no covenant, and no regime contract, as all unfolds from the determinism of nature, or "God", as Spinoza says. Spinoza is not a contractarian philosopher. The state is not based upon any contractual choice but upon natural necessity. Just as an individual is driven by the ambition to survive-principle of conatus, so groups of individuals do the same also when they constitute a dominion, or commonwealth. Just like human beings, they augment survival capacity by employing reason, informing the political authority to promote general well-being, or face competition from another commonwealth or challenge from dominions. Spinoza rejects any choice of opposition or rebellion against the political authority, claiming that people are "bound" to obey. However, such a duty cannot be housed within naturalism. Here, Spinoza breaks with Hobbes.

\section{Society and State}

Social interaction among people in the state of nature, i.e. before government, is all based upon naked power. Some people join in groups for egoistic reasons, which Spinoza calls "dominion". One of these establishes itself as a commonwealth, i.e. a government or state. Thus, Spinoza solves the problem of social order, or how to escape Hobbesian anarchy, by calling in government with sovereign powers. But there is no contract, because also "dominion" or government forms part of nature and necessity. Thus, we have in Tractatus Politicus:

(Q6) UNDER every dominion the state is said to be Civil; but the entire body subject to a dominion is called a Commonwealth, and the general business of the dominion, subject to the direction of him that holds it, has the name of Affairs of State. Next we call men Citizens, as far as they enjoy by the civil law all the advantages of the commonwealth, and Subjects, as far as they are bound to obey its ordinances or laws.

According to naturalism, the competition among dominions or groups leads to one commonwealth or the state, which decides over its people, because it has the power to do so and it takes the general interests into account, because it has reason to fear that it may face resistance otherwise. Thus, government as part of nature has authority or power and it is reasonable to promote general interests in order to avoid uproar and possibly anarchy. This follows logically from enlightened egoism, i.e. naturalism.

The emergence of the state or government belongs to naturalist evolution, where the combat between several dominions or groups finally result in one single dominion, the commonwealth that is most powerful. Consider here the political history of England or Great Britain! 


\section{Political Authority}

If society left to itself tends towards the Hobbesian juggle where we have "omnium bellum contra omnes", how is the problem of political obligation to be solved? Can a commonwealth be stable, controlling anarchy, secession and political violence?

Spinoza admits there is a difficulty with calling up the state and a duty to obey the authority. If a person has the power to disobey, then he or she has the right, as right is power in this approach, i.e. naturalism. It is not, as with Stoicism a justice claim.

Spinoza argues that the political authority, government or the state looks after the well-being of its citizens:

(Q7) For, first of all, it must be considered, that, as in the state of nature the man who is led by reason is most powerful and most independent, so too that commonwealth will be most powerful and most independent, which is founded and guided by reason. For the right of the commonwealth is determined by the power of the multitude, which is led, as it were, by one mind. But this unity of mind can in no wise be conceived, unless the commonwealth pursues chiefly the very end, which sound reason teaches is to the interest of all men.

Spinoza rejects any choice of opposition or rebellion against the political authority, claiming that people are "bound" to obey. However, such a duty is not based upon contract with a consideration. Instead, Spinoza adduces two arguments for the obeisance of citizens towards the government:

- The benevolence of commonwealth: since reason guide government, it looks after general well-being;

- The calculus of individual benefits with obeying against the costs of opposition for an individual.

As a matter of fact, Spinoza constructs a most powerful commonwealth that is not limited by the rule of law or the constitutional state.

\section{The State}

When there are several commonwealths besides each other, then each of them are sovereign. But there can only be one commonwealth for one area or country. Spinoza models the state as a Leviathan:

(Q8) THAT the right of the supreme authorities is limited by their power, we showed in the last chapter, and saw that the most important part of that right is, that they are, as it were, the mind of the dominion, whereby all ought to be guided; and accordingly, that such authorities alone have the right of deciding what is good, evil, equitable, or iniquitous, that is, what must be done or left undone by the subjects severally or collectively. And, accordingly, we saw that they have the sole right of laying down laws, and of interpreting the same, whenever their meaning is disputed, and of deciding whether a given case is in conformity with or violation of the law (Chap. III. Secs. 3-5); and, lastly, of waging war, and of drawing up and offering propositions for peace, or of accepting 
such when offered (Chap. III. Secs. 12, 13).

This amounts to an authoritarian state, where all policy choices are concentrated with government. A stunning implication of Spinoza's naturalism that power is the corner stone in nature, one would be inclined to say. He even rejects "pacta sunt servanda", so underlined in Stoicism:

(Q9) Contracts or laws, whereby the multitude transfers its right to one council or man, should without doubt be broken, when it is expedient for the general welfare to do so. But to decide this point, whether, that is, it be expedient for the general welfare to break them or not, is within the right of no private person, but of him only who holds dominion (Sec. 3); therefore of these laws he who holds dominion remains sole interpreter. Moreover, no private person can by right vindicate these laws, and so they do not really bind him who holds dominion.

We arrive at the classical question: Sed Quis Custodiet Ipsos Custos? Spinoza has two answers to the problem of government oppressing its citizens or some of them. He argues that the commonwealth has reason and it directs them towards the goals of all human beings in nature, viz. peace and security. Even when governments fail these goals, a citizen has no choice but to obey the laws that do not bind government itself. Coherent or not?

This is a most weak argument against government abuse and the insolence of office, leaving the question of political obligation wide open. If government degenerates and bypasses general welfare, then what? It seems that only fear can make citizens obey flawed laws, according to ethical naturalism.

\section{Institutionalism}

Besides naturalism, Spinoza is a strong adherent of institutionalism. It is the framing of the institutions that keeps the commonwealth on its right track towards well-being, peace and security. He engages in a minute examination of the adequate institutions that reason devises. His model is that the dominion is rules by either one person, a few persons or all the people. Every type of dominion can only achieve the natural goals of a commonwealth, namely general well-being.

The argument in Spinoza' political theory is aimed at political realism and avoids moralism. It is much built up upon his theory of human nature, or how people really behave. They are what they are, and theirs emotions can only be restrained by reason and rules:

(Q10) Institutionalism: A dominion then, whose well-being depends on any man's good faith, and whose affairs cannot be properly administered, unless those who are engaged in them will act honestly, will be very unstable. On the contrary, to insure its permanence, its public affairs should be so ordered, that those who administer them, whether guided by reason or passion, cannot be led to act treacherously or basely.

We have come to the middle of the booklet, where Spinoza makes a sharp turn from nature, power and fear to the search for political institutions that enhance the prospects for general welfare.

The emphasis upon rules is key in Spinoza, but it enters the choice proble- 
matic: How to choose the rules that are the best? If people act deterministically, then the choice of rules becomes essential for political outcomes. But choice implies indeterminism! A contradiction with Spinoza?

In a society without government, people feel unsafe and unprotected. Thus, they join in order to set up a commonwealth:

(Q11) INASMUCH as men are led, as we have said, more by passion than reason, it follows, that a multitude comes together, and wishes to be guided, as it were, by one mind, not at the suggestion of reason, but of some common passion-that is (Chap. III. Sec. 9), common hope, or fear, or the desire of avenging some common hurt. But since fear of solitude exists in all men, because no one in solitude is strong enough to defend himself, and procure the necessaries of life, it follows that men naturally aspire to the civil state; nor can it happen that men should ever utterly dissolve it.

But once a commonwealth is in place, the question of rulership arises. It can only be handled by means of institutionalism.

1) One person rule (monarchy)

The risk with monarchy in Spinoza's words or dictatorship today is that the selfish drive of the ruler prevails over the general welfare. Only, institutions can correct for the imbalance between egoism and the common interest as the unity of mind of the commonwealth. Thus, we have the following institutions for the monarchic regime : a set of close councillors, a set of broad councillors, constant change and renewal of councillors who represent the citizens, or a set of "clans" that the population is divided into, no standing army but a quick mobilisation effort to recruit soldiers from the citizenry if needed, a peculiar light taxation scheme based upon public property for the benefit of the monarch, complex system of jurists with oversight functions like public administration and courts, etc. Evidently, Spinoza thought unanimity was a proper decision rule for Parliament as well as the Courts of jurists, as if he did not anticipate transaction costs from such a complex monarchy, institutionally speaking.

Yet, however detailed he rendered these rules of a monarchy for general wellbeing including the family of the majesty, he knew all too well that his naturalism implies a constant temptation by a single ruler to seek more power:

(Q12) It is also certain, that a commonwealth is always in greater danger from its citizens than from its enemies; for the good are few. Whence it follows, that he, upon whom the whole right of the dominion has been conferred, will always be more afraid of citizens than of enemies, and therefore will look to his own safety, and not try to consult his subjects' interests, but to plot against them, especially against those who are renowned for learning, or have influence through wealth.

However, Spinoza assures that if his constitutional monarchy is put in place with all its safeguards, then a stable monarchy for the general well-being is feasible. Perhaps he had England or Sweden in mind. Perhaps one may translate the institutions above to modern terminology with the cabinet as the small set and Parliament as the big set of councillors, while the various sets of jurists would 
make up a system of courts.

2) Rule by a few persons (Aristocracy)

The analysis of oligarchy or the rule of the noble proceeds in the same vein, adding up institutions to restrain egoism. Spinoza comes up again with a long and complicated institutionalisation of the rule of "Best" (Aristos). Thus we face; a primary council of 5000 persons, with so-called syndics as the ministers, a secondary council of senators and courts with jurists. Spinoza delivers strict rules about the soldiers, the city garrisons, payments, etc. Especially, a set of complicated election rules for both councils and jurists is underlined as promoting stability. Moreover, Spinoza separates between patrician rule in a city and a republic of many cities, also run by the few.

Again, institutionalism inspired by historical city states in Italy and the Dutch Republic are called up to restrain patrician rule from degenerating into selfish promotion of narrow self-interests.

(Q13) But it may still be objected to us, that, although the constitution of dominion above set forth is defended by reason and common human passion, yet for all that it may at some time be overpowered. For there is no passion, that is not sometimes overpowered, by a stronger contrary one; for we frequently see the fear of death overpowered by the greed for another's property.

The section of the few's rulership is no doubt empirically inspired, although Spinoza is a rationalist, deducing principles from naturalism and determinism. If the few is a political party like the Communist Party or a Fascist Party, then Spinoza would have something to say why they degenerated in a few historical settings.

3) Rule of the multitude (democracy)

The section on democracy is sad to say not finished, but it would have had the same structure of opposition between naturalist motives and institutionalism. Spinoza states that he regards democracy as a "perfectly absolute dominion" and that he intends to lay down the institutional conditions for its viability. But death stopped the writing with the curious exception of excluding women. $\mathrm{He}$ stated;

(Q14) From what has been said in the last section, it is manifest that we can conceive of various kinds of democracy. But my intention is not to treat of every kind, but of that only, "wherein all, without exception, who owe allegiance to the laws of the country only, and are further independent and of respectable life, have the right of voting in the supreme council and of filling the offices of the dominion".

I will suggest how the Spinoza approach could be continued today by analysing a few relevant institutions myself.

\section{Plebiscitary and Constitutional Democracy}

The rule of the multitude can be done under a minimum of rules or a maximum of institutions. Plebiscitary democracy typically takes the form of big meetings with maximum participation under some decision rule, usually simple majority. 
It is prone to manipulation and the volatility of mob rulership. When plebiscitary democracy is employed over a time period, it sometimes degenerates into totalitarian democracy, as analysed by (Talmon, 1970), due to the zest for power of individuals of small groups. Thus, we arrive at the Spinoza need for institutional build up.

The concept of constitutional democracy contains a number of restraints upon the will of the multitude. There are several institutions of democracy, and only a few will be examined below. It has even been suggested that constitutional democracy may become complex, it hides the so-called people' sovereign will, or "volente generale" (Elster \& Slagstad, 1988).

Following for instance the Federalist Papers (Hamilton, Madison, \& Jay, 1982), plebiscitary democracy in a big state faces the problems of "excesses" either from an aggressive majority or a set of shrewd minorities, like inter alia:

- "The superior force of an interested and overbearing majority.", especially when manipulated baa strongman;

- Factions, or organised minority groups who may collude against the majority.

Thus, we have some institutional remedies like:

- Federalism: divide the state into several states in a Union, with political decentralization, i.e. "state rights";

- Referenda: some decisions may be handed over to direct participation of the demos, either nationally, regionally or locally.

One may mention more of "checks and balances", but here the purpose is to follow in the footsteps of Spinoza, underlining that incentives may sometimes overturn rules or institutions.

With regard to the federalist theory that political decentralisation enhances democratic viability, the evidence is only partial. Several federalist regimes are either authoritarian or unstable or even anarchic. Also unitary states may be stable, promoting general welfare with Spinoza. The danger of federalism is secession, which minorities may exploit to their own advantage.

On the referendum democracy, we the following from a country expert:

(QK) First it should be made clear that a direct democracy can well function as a political system only, if it is designed as a permanent process, rather than if merely individual questions are "picked out" to be presented to the citizens for decisions (Section 2.1). Then there is the question, important in particular for the realm of the European Union, of how direct democracy relates to the unanimity rule (Section 2.2). Section 2.3 discusses the role of quorums. Here, "direct democracy" is always to be understood as a "semi-direct system" in which the representative democracy is supplemented by direct popular rights (Kirschgaessner, 2016: 13).

This quotation states a peculiar view on the referendum institution from the perspective of Swiss public choice theory. As the referendum is employed successfully in completely different ways outside of Switzerland, the tenets here should be rejected. The Swiss system is very transaction cost heavy and open to 
manipulation by minorities as the average level of participation is below $50 \%$. In other countries, the referendum operates as a majoritarian device for deciding issues of high saliency at a few crucial points in time. The referendum is today always supplemented by the indirect system of participation we call political representation. Finally, Wicksell's decision rule-unanimity is not the golden measuring rod of political decision-making that the public choice schools claims. It is transaction cost impossible and invites manipulation-the liberum veto. And Swiss referenda are as far from Wicksell as you can come under a democratic dispensation.

\section{Conclusion}

Spinoza is not only one of 10 - 15 greatest philosophers in the West due to his Ethics (Garrett, 1996). He is also a major politician theoretician as a result of his two treatises, where Tractatus Politicus is much underestimated. Nadler emphasizes that Spinoza' books "lay the foundations for a strongly democratic political thought...". But one may wish to underline the originality of his political philosophy, where democracy is one of three feasible regimes enhancing welfare.

It offers an intriguing enquiry into incentives and institutions that reminds of the principal-agent modelling in the economics of asymmetric information. It is free from any metaphysical assumptions about natural rights in the StoicistLocke-Nozick tradition (Nozick, 1974). Naturalism is the basis, coupled with determinism.

Yet, Spinoza is forced to admit choice, especially with regard to the political regime that promotes general welfare, peace and security. Thus, the latter part of Tractatus Politicus breaks the coherence of the first part. The language of politics is hardly that of determinism but choice. In politics, necessity is replaced by the alternatives of action, calling for a decision. The famous Kierkegaard distinction between ex ante determinism and ex post indeterminism is certainly very helpful in analysing the problem of consistency with Spinoza. Kierkegaard wrote in a translation today: Life can only be understood backwards; but it must be lived forwards (in the Journals of Søren Kierkegaard, 1840s; 1.2.2).

\section{References}

Elster, J., \& Slagstad, R. (1988). Constitutionalism and Democracy. Cambridge: CUP.

Garrett, D. (1996). The Cambridge Companion to Spinoza. Cambridge and New York, NY: Cambridge University Press.

Hamilton, Madison, J., \& Jay, J. (1982). The Federalist Papers. Toronto: Bantam Books.

Kirschgaessner, G. (2016). Direct Democracy: Chances and Challenges. Open Journal of Political Science, 6, 229-249. https://doi.org/10.4236/ojps.2016.62022

Long, A. A., \& Sedley, D. N. (1987). The Hellenistic Philosophers (Vol. 1). Cambridge: CUP.

Long, A. A., \& Sedley, D. N. (2012). The Hellenistic Philosophers (Vol. 2). Greek and Latin Texts with Notes and Bibliography. Cambridge: CUP.

Nozick, R. (1974). Anarchy, State and Utopia. New York, NY: Basic Books. 
Nadler, S. (1999). Spinoza: A Life. Cambridge and New York, NY: Cambridge University Press. https://doi.org/10.1017/CBO9780511815713

Nadler, S. (2016). Baruch Spinoza. The Stanford Encyclopedia of Philosophy (Fall 2016 ed.). https://plato.stanford.edu/archives/fall2016/entries/spinoza/

Popkin, R. (2004). Spinoza. Oxford: One World.

Scruton, R. (2002). Spinoza-A Very Short Introduction. Oxford: OUP. https://doi.org/10.1093/actrade/9780192803160.001.0001

Spinoza a, B. The Ethics [Ethica Ordine Geometrico Demonstrata]. Translated by R. H. M. Elwes. https://ebooks.adelaide.edu.au//spinoza/benedict/

Spinoza b, B. Theologico-Political Treatise. Translated by R. H. M. Elwes. https://ebooks.adelaide.edu.au//spinoza/benedict/

Spinoza c, B. Political Treatise [Tractatus Politicus]. Translated by R. H. M. Elwes. https://ebooks.adelaide.edu.au//spinoza/benedict/

Talmon, J. L. (1970) Origins of Totalitarian Democracy. New York, NY: Norton. Tuck, R. (1982) Natural Rights Theories. Cambridge: CUP.

Submit or recommend next manuscript to SCIRP and we will provide best service for you:

Accepting pre-submission inquiries through Email, Facebook, LinkedIn, Twitter, etc. A wide selection of journals (inclusive of 9 subjects, more than 200 journals)

Providing 24-hour high-quality service

User-friendly online submission system

Fair and swift peer-review system

Efficient typesetting and proofreading procedure

Display of the result of downloads and visits, as well as the number of cited articles Maximum dissemination of your research work

Submit your manuscript at: http://papersubmission.scirp.org/

Or contact ojpp@scirp.org 